\title{
OPTIMALISASI PRAMUWISATA DALAM PELAYANAN KEPARIWISATAAN DI KABUPATEN SUMENEP
}

\author{
Oleh: \\ Meiry Soraya, Hadi Soetarto, Nur Inna Alfiyah \\ Program Studi Administrasi Publik Fakultas Ilmu Sosial dan Ilmu Politik \\ Universitas Wiraraja
}

\begin{abstract}
Abstrak
Masalah yang diteliti dalam skripsi ini Bagaimanakah Optimalisasi Pramuwisata Dalam Pelayanan Kepariwisataan Di Kabupaten Sumenep, sedangkan tujuan penelitian Untuk Mengetahui Optimalisasi Pramuwisata Dalam Pelayanan Kepariwisataan Di Kabupaten Sumenep. Metode penelitian deskreptif kualitatif, dengan fokus penelitian yaitu 1) To conduct to direct, 2) To point out, dan 3), To inform. Subjek penelitian ini informan kunci, utama dan pendukung, teknik pengumpulan data interview, observasi dan dokumentasi, dengan analisa data dengan pendekatan reduksi data dan verifikasi data. Hasil penelitian menunjukkan menunjukkan pramuwisata dapat memberikan pelayanan kepariwisataan yang sangat optimal kepada kunjungan wisatawan kei Kabupaten Sumenep, yang terlihat dari To Conduct To Direct yang mengatur dan melaksanakan kegiatan perjalanan wisata, dan To Point Out mengantarkan perjalanan wisatawan ke objek-objek dan daya tarik wisata yang dikehendaki, agar wisatawan merasakan kenyamanan serta To Inform, pramuwisata memberikan informasi dan penjelasan mengenai objek dan daya tarik wisata yang dikunjungi. Pemanduan wisata yang dilakukan oleh Pramuwisata asuhan Dinas Pariwisata, Kebudayaan,Pemuda dan Olah Raga Kabupaten Sumenep telah menunjukkan adanya optimalisasi tugas sebagai pramuwisata dalam mengantarkan dan dan mendampingi wisatawan di Kabupaten Sumenep.
\end{abstract}

Kata Kunci : Optimalisasi, Pelayanan Pariwisata dan Pramuwisata

\section{Abstract}

Problem that is analyzed in this paper How Optimalisasi Pramuwisata In Ministering tourism At Regency Sumenep, meanwhile to the effect research To Know Optimalisasi Pramuwisata In Ministering tourism At Regency Sumenep. Deskreptif kualitatif's observational method, with observational focus which is 1 ) To conduct to direct, 2 ) To point out, and 3), To inform. Subjek is this research key informan, main and supporting, interview's data collecting tech, observation and documentation, with data analysis with data reduction approaching and data verification. Result observationaling to point out pramuwisata can give tourism service that really optimal to kei's touristed visit Sumenep's Regency, one that looked of To Conduct To direct one that manages and perform wisata's trip activity, and To Point Out delivering touristed trip goes to wisata's object and affinity that is wanted, that tourist feels convenience and To Inform, $p$ ramuwisata gives information and explanation hit wisata's object and affinity that visited. wisata's pilotage that did by Pramuwisata upbringing on duty Tourism, Culture,Young men and Sumenep's Regency Sport no has pointed out to mark sense optimalisasi task as pramuwisata in delivers and and adjoin tourist at Regency Sumenep.

Key word: Optimalisasi, Tourism service andPramuwisata

\section{PENDAHULUAN}

$\begin{array}{rcr}\text { Pengelolan wisata } & \text { memasang } \\ \text { staretgi untuk menarik } & \text { perhatian }\end{array}$

wisatawan, selain tempat yang disediakan mudah untuk dijangkau, pemasaran yang baik dan pelayanan yang prima juga harus disediakan. Pariwisata sekarang ini penuh dengan persaingan. 
Kabupaten Sumenep yang memiliki beberapa kekuatan daya tarik, seperti iklim yang baik, atraksi pemandangan yang beragam, budaya yang menarik dan sejarah, masyarakat yang ramah dan bersahabat, akomodasi khas, gaya hidup, dan harga yang pantas. Ragam obyek wisata di Kabupaten Sumenep seluruhnya terdiri atas wisata budaya, wisata alam, wisata sejarah, wisata religi, wisata kuliner, wisata minat khusus.

Optimalisasi yang dilakukan Dinas Pariwisata, Kebudayaan, Pemuda dan Olah Raga Kabupaten Sumenep, dilihat masih belum optimal. Kabupaten Sumenep mempunyai 28 destinasi wisata yang terdata. (8 wisata Religi, 13 wisata Alam, 3 wisata sejarah dan 4 wisata buatan). Destinasi yang berlisensi Dinas Pariwisata, Kebudayaan, Pemuda dan Olahraga (Disparbudpora) Sumenep yang mengelola 3 objek wisata, baru mempunyai 14 pemandu wisata (Tour Guide) berlesensi.

Kunjungan wisatawan tahun 2018 wisatawan yang berkunjung ke Kabupaten Sumenep di targetkan mencapai 1 juta pengunjung, namun kunjungan wisatawan lebih banyak dari yang ditargetkan dengan total kunjungan wisatwan mencapai 1.457.766 orang. Pada tahun 2019 kunjungan wisatawan sejak Januari hingga Desember 2019 mencapai 840.905 orang dengan target kunjungan wisata sebanyak 1.498.000 wisatawan, masih kurang memenuhi target yang ada (Sumber : Disparbudpora, 2020).

Keberadaan pemandu wisata yang ada di Kabupaten Sumenep, dibawah naungan Dinas Pariwisata, Kebudayaan dipandang perlu pramuwisata untuk memberikan pemahaman sejarah historis setiap destinasi yang menjadi tujuan pengunjung wisata ketika ke Sumenep. Ditambah lagi keberadaan tenaga pemandu wisata di Sumenep juga belum mempunyai lembaga yang dinaungi dinas terkait. Sejauh ini 14 guide yang berlesensi tersebut dinyatakan masuk di Himpunan Pramuwisata Indonesia (HPI) Sumenep.

Adanya pramuwisata yang bersentuhan langsung dengan wisatawan dapat mempengaruhi kunjungan wisatawan. Untuk itu pelayanan yang optimal dari pramuwisata diharapkan dapat diberikan pemandu wisata agar kunjungan wisatawan dapat bertambah dan target kunjungan wisatawan dapat terpenuhi atau bahkan melebihi target yang telah ditentukan. Apalagi di Sumenep masih belum ada organisasi tentang pramuwisata.

Optimalisasi pengelola wisata sebagai daya tarik dan kondisi suatu obyek atau daerah sangat berpengaruh pada waktu kunjungan wisatawan. Wisatawan akan cenderung cepat meninggalkan lokasi apabila obyek yang ada tidak atraktif dan terkesan tidak menarik (Tim Pariwisata, Seni dan Budaya Kab. Sumenep, 2020). 
Dinas Periwisata, Pemuda dan Olah Raga Kabupaten Sumenep, untuk mampu dalam pengelolaan sumber daya yang bagus, baik sumber daya alam maupun sumber daya manusia di desa wisata ini harus dibina semaksimal mungkin. Pemandu wisata sebanyak 14 orang menjadi lebih profesional dalam mengembangkan destinasi wisata sesuai dengan komitmen organisasi dalam mempromosikan desa wisata yang ada di Kabupaten Sumenep. Termasuk profesionalisme pengelola wisata dalam mempromosikan atau mengenalkan wisata kepada wisatawan yang datang, karena profesionalisme kerja pegawai sebagai suatu sikap dan keramah tamahan dalam menyajikan kepariwisata secara menawan sehingga wisatawan benar - benar tertarik dalam wisatanya.

Berdasarkan permasalahan tersebut, maka pada intinya pengelola desa wisata, pramuwisata masih kurang optimal dalam memasarkan tempat wisata, karena masih perlu dilakukan perbaikanperbaikan, karena bagaimanapun juga pendidikan, kompetensi dan motivasi serta profesionalisme sangat berpengaruh terhadap kinerja pramuwisata dalam berpromosi dalam memasarkan destinasi wisata. Pembinaan tersebut menjadi bagian dari upaya mewujudkan pelaksanaan good governance di setiap unit organisasi pemerintahan, sehingga terwujudnya pengelola wisata yang memiliki kompetensi yang sesuai profesionalismenya dan tentunya agar mampu mencapai kinerja yang diharapkan. Adanya permasalahan tersebut, maka peneliti ingin mengkaji lebih dalam lagi tentang Optimalisasi Pramuwisata dalam Pelayanan Kepemanduan Wisata. Maka dari itu peneliti tertarik untuk mengangkat judul "Optimalisasi Pramuwisata Dalam Pelayanan Kepariwisataan Di Kabupaten Sumenep."

Berdasarkan uraian pada latar belakang permasalahan diatas maka rumusan masalah yang diangkat penulis adalah Bagaimanakah Optimalisasi Pramuwisata Dalam Pelayanan Kepariwisataan Di Kabupaten Sumenep. Tujuan penelitian pada dasarnya hendak menjawab rumusan masalah diatas, maka tujuan penelitian ini adalah : Untuk Mengetahui Optimalisasi Pramuwisata Dalam Pelayanan Kepariwisataan Di Kabupaten Sumenep.

\section{TINJAUAN TEORITIS}

\section{Optimalisasi}

Dalam beberapa literatur manajemen,tidak dijelaskan secara tegas pengertian optimalisasi, namun dalam Kamus Bahasa Indonesia, Poerdwadarminta 2012 753 ) dikemukakan bahwa : "Optimalisasi adalah hasil yang dicapai sesuai dengan keinginan, jadi optimalisasi 
merupakan pencapaian hasil sesuai harapan secara efektif dan efisien".

Optimalisai banyak juga diartikan sebagai ukuran dimana semua kebutuhan dapat dipenuhi dari kegiatan - kegiatan yang dilaksanakan.

Menurut Winardi (2014: 363) Optimaslisai adalah ukuran yang menyebabkan tercapainya tujuan sedangkan jika dipandang dari sudut usaha, Optimalisasi adalah usaha memaksimalkan kegiatan sehingga mewujudkan keuntungan yang diinginkan atau dikehendaki.

Optimalisasi juga dapat didefinisikan sebagai proses untuk mendapatkan keadaan yang memberikan nilai maksimum atau minimum dari suatu fungsi. .Optimalisasi adalah tindakan untuk memperoleh hasil yang terbaik dengan keadaan yang diberikan. Dalam desain, konstruksi, dan pemeliharaan dari sistem teknik, harus diambil beberapa teknologi dan keputusan managerial dalam beberapa tahap. Tujuan akhir dari semua keputusan seperti itu adalah meminimalkan upaya yang diperlukan atau untuk memaksimalkan manfaat yang diinginkan.

\section{Pramuwisata}

Menurut Yoeti (dalam Udoyono, 2013 : 18) pramuwisata adalah seseorang yang menerangkan, menjelaskan, serta memberi petunjuk kepada wisatawan tentang segala sesuatu yang akan dilihat, disaksikan oleh wisatawan, pada saat berkunjung ke suatu objek, tempat atau daerah tertentu.

$$
\text { Menurut Yoeti (2010 : 76) }
$$

pramuwisata atau tour guide adalah orang yang bertugas memberikan bimbingan, informasi, dan petujuk tentang atraksi atau destinasi.

Seorang pramuwisata harus dapat memberi kesenangan atapun kepuasan kepada setiap yang dibawanya. Oleh karena itu, untuk mengetahui keinginan dan selera wisatawan, hendaknya seorang pramuwisata menyatukan pengetahuan, keterampilan, dan perasaannya demi tercapainya kesenangan yang diinginkan oleh wisatawan yang dibawanya tersebut.

Pendapat Nuriata (2015 : 98) Pramuwisata dapat menjadi mediator, penyalur kebutuhan wisatawan dalam perjalanannya dan dapat menjadi mediator untuk kepentingan pada pemerintah masyarakat, lembaga-lembaga non pemerintah, maupun dengan semua fasilitas wisata sebagai pendukung perjalanan, seperti dengan Hotel, Transportasi, Pengelola Atraksi Wisata, dan sebagainya.

Jenis pemandu wisata menurut Muhajir (2015 : 68) dibagi berdasarkan tempat melaksanakan tugasnya, dibedakan menjadi Local Guide dan City Guide, selanjutnya akan dijelaskan sebagai berikut:

1. Lokal Guide atau pemandu wisata lokal 
yaitu seorang pemandu wisata yang menangani suatu tour selama satu atau beberapa jam di suatu tempat yang khusus, pada suatu atraksi wisata atau di suatu areal yang terbatas, misalnya gedung bersejarah, museum, taman hiburan dan lain- lain.

\section{City Guide}

adalah pemandu wisata yang bertugas membawa wisatawan dan memberikan informasi wisata tentang objek-objek wisata utama di suatu kota, biasanya dilakukan di dalam bus atau kendaraan lainnya.

Menurut Yoeti (2010 : 87) pramuwisata adalah orang yang bertugas memberikan bimbingan, informasi dan petunjuk tentang atraksi atau dimensi, sedangkan jenis- jenis pramuwisata terbagi menjadi:

1. Berdasarkan Tempat

Melaksanakan Tugas, terdiri dari:

a) Local Guide (on-site guide), b)

City Guide.

2. Berdasarkan Spesifikasi, terdiri dari:
a) Pramuwisata Khusus,

Pramuwisata Umum.

3. Berdasarkan Asal Wisatawan dan Wilayah Negara Tempat dilaksanakannya Tour, terdiri: a) inbound tour guide, b) Out- bound tour guide, c) Domestic tour guide.

4. Berdasarkan Status, terdiri: a) payroll guide, b) Freelance guide.

5. Berdasarkan Tingkatan, berdasarkan keputusan menteri pariwisata, pos dan telekomunikasi nomor KM 82/PW 102/MPPT-88 tentang pramuwisata dan pengatur wisata, pemandu wisata (pramuwisata) dikelompokkan sebagai berikut: a) Pramuwisata Muda, b) Pramuwisata Madya, c) Pengatur Wisata.

6. Berdasarkan Jumlah Wisatawan Yang Ditangani, terdiri: a) Group Tour Guide, b) Individual Tour Guide.

Pemandu wisata menurut Irawati (2013 : 107) merupakan pemimpin dalam suatu perjalanan wisata, secara umum tugas seorang pemandu wisata adalah sebagai berikut:

\section{To conduct to direct}

yaitu mengatur dan melaksanakan kegiatan perjalanan wisata bagi wisatawan yang ditanganinya berdasarkan program perjalanan yang telah ditetapkan.

2. To point out,

yaitu menunjukkan dan mengantarkan wisatawan ke objekobjek dan daya tarik wisata yang dikehendaki.

\section{To inform}

yaitu memberikan informasi dan penjelasan mengenai objek dan daya tarik wisata yang dikunjungi, 
informasi sejarah dan budaya, dan berbagai informasi lainnya.

Pendapat lain mengenai tugas pemandu wisata yang disampaikan oleh Nuriata (2015 : 97) terdapat beberapa tugas inti pemandu wisata yang berhubungan dengan keterampilan berkomunikasi antara lain:

1. Pembimbing perjalanan.

2. Memperkenalkan berbagai macam benda, barang, dan segala yang terkait dengan perjalanan.

3. Memberikan interpretasi mengenai atraksi wisata yang ditemui dalam perjalanan wisata.

4. Memberikan informasi tentang perjalanan wisata.

5. Memberikan saran mengenai pelaksanaan perjalanan wisata.

Pramuwisata dapat dikelompokan berdasarkan sudut pandang yang dibagi menjadi tiga yaitu berdasarkan kegiatan, dan karakteristik wisatawan (Udoyono, 2008), yaitu :

1. Berdasarkan ruang lingkup kegiatannya

\section{a. Transfer guide}

adalah menjemput wisatawan di bandara, pelabuhan, stasiun atau terminal menuju ke hotel hotel atau sebaliknya.

b. Walking guide/Tour Guide adalah yang memandu wisatawan dalam suatu tur yang dilakukan dengan cara berjalan kaki.

c. Local/expert guide adalah pramuwisata memandu wisatawan pada suatu objek atau atraksi wisata tertentu, misalnya museum, wisata agro, river rafting, goa, gedung bersejarah, dan lainlain.

d. Common guide adalah pramuwisata yang dapat melaku kan kegiatan baik transfer maupun tur.

e. Driver guide

adalah pengemudi yang sekaligus berperan sebagai Pramuwisata. Pramuwisata ini bertugas mengantarkan wisatawan ke objek atau atraksi wisata yang dikehendaki sekaligus memberikan informasi yang diperlukan.

2. Berdasarkan status

a. Payroll guide

Adalah pramuwisata yang berstatus sebagai pegawai tetap

b. Part timer/Free lance guide adalah pramuwisata yang bekerja pada suatu perusahaan perjalanan untuk kegiatan 
tertentu dan dibayar untuk tiap pekerjaan yang dilakukan, serta tidak terikat oleh suatu perusahaan.

c. Member of guide association adalah pramuwisata yang bersatus sebagai peserta dari suatu asosiasi dan melakukan kegiatannya sesuai dengan tugas yang diberikan oleh asosiasi tersebut. Sebagai contoh anggota himpunan pramuwisata indonesia (HPI).

d. Government officials

adalah pegawai pemerintah yang bertugas untuk memberikan informasi kepada tamu tentang aktivitas, gedung, atau suatu wilayah tentu.

e. Company guide

adalah karyawan sebuah perusahaan yang bertugas memberikan penjelasan kepada tamu tentang aktivitas atau objek perusahaan. Perusahaan perjalanan (travel agent) dengan mendapat gaji tetap di samping komisi dan tip yang diterima dari wisatawan.

\section{Pariwisata}

Undang-Undang Republik Indonesia Nomor 10 Tahun 2009 Tentang Kepariwisatawan, maka wisata didefinisikan sebagai kegiatan perjalanan atau sebagian dari kegiatan tersebut yang dilakukan secara sukarela serta bersifat sementara untuk menikmati obyek dan daya tarik serta pesona wisata.

Sedangkan pariwisata diartikan sebagai segala sesuatu yang berhubungan dengan wisata, termasuk pengusahaan obyek dan daya tarik wisata serta usahausaha yang terkait di bidang tersebut.

Definisi yang lebih umum disampaikan Freddy (2011 : 8) yang menerjemahkan bahwa secara terminologis, pariwisata berarti suatu kegiatan rekreatif dengan melakukan suatu perjalanan yang bertujuan untuk mendapatkan kenikmatan, mencari kepuasan, mengetahui sesuatu, memperbaiki kesehatan, menikmati olahraga atau istirahat, menunaikan tugas, dan berziarah. Pada akhirnya, seiring dengan perkembangan waktu, pada saat ini kegiatan pariwisata tumbuh dan berkembang sedemikian rupa menjadi suatu bentuk industri yang kemudian dimodifikasi, sehingga bermunculan pula definisi dari pariwisata yang mencerminkan sudut pandang ataupun kepentingan masing-masing.

Sekian banyak jenis pariwisata, maka sesuai dengan objek yang dijual, 
kemudian dikenal wisata alam, wisata budaya, wisata sejarah, wisata arkeologi, wisata bahari, dan wisata pendidikan. Dilihat dari tujuan berwisata, maka dapat digolongkan menjadi wisata religi, wisata nostalgia, wisata belanja, wisata berburu, wisata petualangan, dan wisata kesehatan. Sedangkan apabila digolongkan berdasarkan karakteristik peserta, tumbuh wisata anak-anak, wisata remaja, maupun wisata wredha. (Wijiatmoko, 2014 : 18).

Daerah tujuan wisata menurut Surjanto (dalam A. Karyono, 2013 : 97 yaitu daerah-daerah yang berdasarkan kesiapan prasarana dan sarana dinyatakan siap menerima kunjungan wisatawan di Indonesia. Daerah tujuan wisata diharuskan memiliki objek wisata dan daya tarik wisata sebagai media untuk menarik minat wisatawan.

Sebagaimana Bab II Pasal 3 Kepariwisataan berfungsi memenuhi kebutuhan jasmani, rohani, dan intelektual setiap wisatawan dengan rekreasi dan perjalanan serta meningkatkan pendapatan negara untuk mewujudkan kesejahteraan rakyat. Pada pasal 4, bahwa Kepariwisataan bertujuan untuk :
a. Meningkatkan
pertumbuhan
ekonomi;
b. meningkatkan kesejahteraan rakyat;
c. menghapus kemiskinan;
d. mengatasi pengangguran;
e. melestarikan alam, lingkungan,

dan sumber daya;

f. memajukan kebudayaan;

g. mengangkat citra bangsa;

h. memupuk rasa cinta tanah air;

i. memperkukuh jati diri dan kesatuan bangsa; dan

j. mempererat persahabatan antar bangsa.

Tujuan wisata dapat memberikan kenyamanan bagi wisatawan sesuai dengan keinginan yang akan dituju wisatawan, karena berfungsi memberikan kesenangan dalam melakukan wisata bersama sama ataupun dilakukan secara sendiri.

Pengembangan kawasan wisata merupakan alternatif yang diharapkan mampu mendorong baik potensi ekonomi maupun upaya pelestarian. Pengembangan kawasan wisata dilakukan dengan menata kembali berbagai potensi dan kekayaan alam dan hayati secara terpadu. Pada tahap berikutnya dikembangkan model pengelolaan kawasan wisata yang berorientasi pelestarian lingkungan (Ramly, $2011: 71)$.

Disamping itu untuk dapat melakukan pengembangan perlu memperhatikan berbagai aspek, suatu objek wisata yang akan dikembangkan harus memperhatikan syarat-syarat pengembangan daerah menjadi objek wisata yang dapat diandalkan, yaitu :

1. Seleksi terhadap potensi, hal ini dilakukan untuk memilih dan 
menentukan potensi objek wisata yang memungkinkan untuk dikembangkan sesuai dengan dana yang ada.

2. Evaluasi letak potensi terhadap wilayah,

pekerjaan ini mempunyai latar belakang pemikiran tentang ada atau tidaknya pertentangan atau kesalahpahaman antar wilayah administrasi yang terkait.

3. Pengukuran jarak antar potensi, pekerjaan ini untuk mendapatkan informasi tentang jarak antar potensi, sehingga perlu adanya peta agihan potensi objek wisata.

Menurut Suwantoro, (2011 : 97). Pembangunan suatu objek wisata harus dirancang dengan bersumber pada potensi daya tarik yang dimiliki objek tersebut dengan mengacu pada kriteria keberhasilan pengembangan yang meliputi berbagai kelayakan, antara lain :

1. Kelayakan Finansial

Studi kelayakan ini menyangkut perhitungan secara komersial dari pembangunan objek wisata tersebut. Perkiraan untung-rugi sudah harus diperkirakan dari awal.

2. Kelayakan Sosial Ekonomi Regional Studi kelayakan ini dilakukan untuk melihat apakah investasi yang ditanamkan untuk membangun suatu objek wisata juga akan memiliki dampak sosial ekonomi

secara

regional; dapat menciptakan lapangan kerja/berusaha, dapat meningkatkan penerimaan devisa, dapat meningkatkan penerimaan pada sektor yang lain.

3. Layak Lingkungan

Analisis dampak lingkungan dapat dipergunakan sebagai acuan kegiatan pembangunan suatu objek wisata. Pembangunan objek wisata yang mengakibatkan rusaknya lingkungan harus dihentikan pembangunannya.

Pembangunan objek wisata bukanlah untuk merusak lingkungan tetapi sekedar memanfaatkan sumber daya alam untuk kebaikan manusia sehingga menjadi keseimbangan, keselarasan dan keserasian hubungan antara manusia dengan manusia, manusia dengan lingkungan alam dan manusia dengan Tuhannya.

Unsur pendukung yang harus mendapat perhatian guna menunjang pengembangan pariwisata didaerah tujuan wisata menurut Yoeti, (2015 : 82) meliputi:

a. Obyek dan Daya Tarik Wisata

Daya tarik wisata yang juga disebut obyek wisata merupakan potensi yang menjadi pendorong kehadiran wisatawan ke suatu daerah tujuan wisata. Pada umumnya daya tarik suatu obyek wisata berdasar pada

b. Prasarana Wisata 
Prasarana wisata adalah sumber daya alam dan sumber daya buatan manusia yang mutlak dibutuhkan oleh wisatawan dalam perjalanannya di daerah tujuan wisata, seperti jalan, listrik, air, telekomunikasi, terminal, jembatan dan lain sebagainya.

c. Sarana Wisata

Sarana wisata merupakan kelengkapan daerah tujuan wisata yang diperlukan untuk melayani kebutuhan wisatawan dalam menikmati perjalanan wisatanya. Berbagai sarana wisata yang harus disediakan di daerah tujuan wisata ialah hotel, biro perjalanan, alat transportasi, restoran dan rumah makan serta sarana pendukung lainnya.

\section{Profesionalisme}

Pramuwisata sebagai pekerjaan profesi yang merupakan pekerjaan yang didalamnya memerlukan sejumlah persyaratan yang mendukung pekerjaannya. Karena itu, tidak semua pekerjaan menunjuk pada suatu profesi.

Dengan demikian profesi memang sebuah pekerjaan, tetapi sekaligus tidak sama begitu saja dengan pekerjaan pada umumnya.

Profesi mempunyai tuntutan yang sangat tinggi, bukan saja dari luar melainkan terutama dari dalam diri orang itu sendiri. Tuntutan ini menyangkut tidak saja keahlian, melainkan juga komitmen moral: tanggung jawab, keseriusan, disiplin dan integritas pribadi (Keraf, 2008:19).

Profesional yaitu serangkaian keahlian yang dipersyaratkan untuk melakukan suatu pekerjaan yang dilakukan secara efisien dan efektif dengan tingkat keahlian yang tinggi dalam rangka untuk mencapai tujuan pekerjaan yang maksimal. Orang profesional sebagaimna pramuwisata adalah orang yang melakukan suatu pekerjaan karena ahli dibidang tersebut dan meluangkan seluruh waktu, tenaga, dan perhatianya untuk pekerjaan tersebut. Orang yang profesional adalah orang yang mempunyai komitmem pribadi yang mendalam atas pekerjaan, melibatkan seluruh dirinya dengan giat, tekun dan serius menjalankan pekerjaannya. Disiplin dan keseriusan adalah perwujudan dari komitmen atas pekerjaannya. Orang profesional diandalkan dan dipercaya masyarakat karena mempunyai komitmen moral/pribadi serta tanggung jawab yang mendalam atas pekerjaannya (Keraf, 2008: 57).

Menurut Hamalik (2010 : 83) profesionalisme pada hakekatnya mengandung beberapa aspek :

1. Aspek potensial, bahwa setiap tenaga kerja memiliki potensi-potensi herediter yang bersifat dinamis yang terus 
berkembang dan dapat dikembangkan. Potensi-potensi itu antara lain : daya mengingat, daya berfikir, bakat dan minat, motivasi, dan potensi-potensi lainnya.

2. Aspek profesionalisme atau vokasional, bahwa setiap tenaga kerja memiliki kemampuan dan keterampilan kerja atau kejujuran dalam bidang tertentu dengan kemampuan dan keterampilan itu dia dapat mengabdikan dirinya dalam lapangan kerja tertentu dan menciptakan hasil yang baik secara optimal.

3. Aspek fungsional, bahwa setiap melaksanakan pekerjaannya secara tepat guna, artinya dia bekerja sesuai dengan tugas dan fungsinya dalam bidang yang sesuai pula. Misalnya tenaga kerja yang memiliki keterampilan dalam bidang elektronik seharusnya bekerja dalam bidang pekerjaan elektronik bukan bekerja sebagai tukang kayu untuk bangunan.

4. Aspek operasional, bahwa setiap tenaga kerja dapat mendayagunakan kemampuan dan keterampilannya dalam proses dan prosedur pelaksanaan kegiatan kerja yang sedang ditekuninya.

5. Aspek personal, bahwa setiap tenaga kerja harus memiliki sifat-sifat kepribadian yang menunjang pekerjaannya, misalnya sikap mandiri dan tangguh, bertanggung jawab, tekun dan rajin, mencintai pekerjaannya, berdisiplin dan berdedikasi yang tinggi.

6. Aspek produktifitas, bahwa setiap tenaga kerja harus memiliki motif berprestasi, berupaya agar berhasil, dan memberikan hasil dari pekerjaanya baik kuantitas maupun kualitas.

Karakteristik dan Ciri Profesionalisme Anoraga (2016 : 53) dikemukakan beberapa ciri profesionalisme yaitu :

1. Profesionalisme menghendaki sifat mengejar kesempurnaan hasil, sehingga dituntut untuk selslu mencari peningkatan mutu.

2. Profesionalisme memerlukan kesungguhan dan ketelitian kerja yang hanya dapat diperoleh melalui pengalaman dan kebiasaan.

3. Profesionalisme menuntut ketekunan dan ketabahan, yaitu sifat tidak mudah puas atau putus asa sampai hasil tercapai.

4. Profesionalisme memerlukan integritas tinggi yang tidak tergoyahkan oleh "keadaan terpaksa" atau godaan iman seperti harta dan kenikmatan hidup.

5. Profesionalisme memerlukan adanya 
kebulatan fikiran dan perbuatan, sehingga terjaga efektivitas kerja yang tinggi.

Selain itu, menurut Jatman (2002) (dalam Rahman 2013) bahwa dimensi profesionalisme secara umum adalah:

1. Altruisme yaitu berani berkorban, mementingkan orang lain bukan diri sendiri, hal ini ditunjukan melalui sikap suka membantu, problem solver, membuat keputusan secara tepat dan obyektif.

2. Komitmen terhadap kesempurnaan, sikap profesionalnya yaitu efektif dan efisien, memberikan atau mengerjakan yang terbaik.

3. Toleransi, sikap profesionalnya ditunjukan dengan sikap adaptasi, suka bekerjasama, komunikatif, bijaksana, dan meminta tolong jika memang memerlukan.

4. Integritas dan karakter, sikap profesionalnya ditunjukan melalui sikap jujur, teguh, tidak plin-plan, percaya diri, berjiwa pemimpin yang memberi teladan.

5. Respek kepada semua orang, profesional dalam menerima kritik, menepati janji, memegang rahasia, menghormati orang lain dan tahu diri.

6. Sense of duty, sikap profesionalnya adalah disiplin dan tepat waktu.

Langkah awal yang harus ditempuh agar seseorang dapat berstatus sebagai profesional adalah mempunyai kemampuan intelektualnya yang cukup, yaitu suatu kemampuan yang berupa mampu untuk mudah memahami, mengerti, mempelajari dan menjelaskan suatu fenomena. Artinya tingkat, derajat, kualitas dan kuantitas profesionalisme dapat dilihat dari berapa banyak dan berapa tingginya kualitas masyarakat intelektual yang ada bagi mendukung profesionalisme tersebut.

\section{METODE PENELITIAN}

Fokus penelitian yang diambil dalam penelitian optimalisasi pramuwisata yang digunakan peneliti mengacu tugas pramuwisata berdasarkan teori Irawati (2013 : 107), yaitu:

\section{To conduct to direct}

Mengatur dan melaksanakan kegiatan perjalanan wisata bagi wisatawan yang ditanganinya berdasarkan program perjalanan yang telah ditetapkan.

2. To point out,

Menunjukkan dan mengantarkan perjalanan wisatawan ke objekobjek dan daya tarik wisata yang dikehendaki, agar wisatawan merasakan kenyamanan dalam berwisata.

3. To inform

Memberikan informasi dan penjelasan mengenai objek dan daya 
tarik wisata yang dikunjungi, informasi sejarah dan budaya, dan berbagai informasi lainnya.

Sumber data penelitian sebagai langkah terpenting khususnya menentukan metode penulisan data. Arikunto (2016 : 107) menyebutkan bahwa sumber data terdiri dari tiga yaitu Person, Place dan Paper, dilihat dari jenisnya, dapat dibedakan menjadi :

1. Data primer

Data primer adalah pengambilan data dengan instrumen pengamatan, wawancara, catatan lapangan dan penggunaan dokumen. Sumber data primer merupakan data yang diperoleh langsung dengan teknik wawancara informan atau sumber langsung. Sumber primer adalah sumber data yang langsung memberikan data kepada pengumpul data.

2. Data sekunder

Sumber data sekunder adalah data yang digunakan untuk mendukung data primer yaitu melalui studi kepustakaan, dokumentasi, buku, majalah, koran, arsip tertulis yang berhubungan dengan obyek yang akan diteliti pada penelitian ini.

Instrumen merupakan suatu alat yang digunakan untuk mengukur fenomena (variabel penelitian) yang diamati secara spesifik dilapangan
(Sugiyono, 2016 : 119), yaitu :

1. Peneliti sendiri

Peneliti melakukan observasi dengan cara terlibat secara langsung dalam obyek yang akan diteliti khususnya pada objek penelitian yang dipilih, dengan mempergunakan tape recorder maupun hand pone.

2. Pedoman wawancara

Panduan wawancara yang sudah tertulis dan sesuai dengan permasalahan fakta yang diangkat dalam fokus penelitian, menggunakan tape recorder.

3. Observasi :

Data yang diperoleh secara langsung di objek penelitian dengan cara melakukan pengamatan dan mencatat berbagai hasil pengamatan sesuai data yang akan diperoleh sebagai fokus.

4. Dokumentasi

Proses mengamati obyek penelitian yang diakhiri dengan pengumpulan berbagai data-data, dokumen atau file, dan beragam kegiatan penelitian yang diambil dan disajikan melalui gambar atau fotofoto selama melakukan penelitian.

Penelitian ini menggunakan pendekatan kualitatif, maka subjek dalam penelitian ini sebanyak :

1. Informan Kunci 
yaitu orang-orang yang sangat memahami permasalahan yang diteliti. Adapun yang dimaksud sebagai informan kunci dalam penelitian ini adalah Kepala Bidang Pariwisata Dinas Pariwisata Kebudayaan Pemuda dan Olahraga Kabupaten Sumenep.

2. Informan Utama, mereka yang terlibat langsung dalam kepariwisataan yang diteliti. Adapun sebagai informan utama dalam penelitian ini adalah Kasi Pemberdayaan Sumber Daya Pariwisata Dinas Pariwisata Kebudayaan Pemuda dan Olahraga Kabupaten Sumenep dan Pramuwisata.

3. Informan Pendukung yaitu informan yang ditentukan dengan dasar pertimbangan memiliki pengetahuan dan sering berhubungan baik secara formal maupun informal dengan para informan kunci. Adapaun yang dimaksud sebagai informan pendukung dalam penelitian ini adalah Wisatawan yang berkunjung ke Kabupaten Sumenep

Teknik Pengumpulan Data dalam penelitian yang diperlukan, peneliti menggunakan teknik pengumpulan data sebagai berikut:

1. Wawancara wawancara adalah pertemuan dua orang untuk bertukar informasi dan ide melalui tanya jawab, sehingga dapat dikonstruksikan makna dalam suatu topik tertentu. Peneliti melakukan wawancara dan bertatap muka dengan informan dalam menggali data penelitian.

2. Observasi

Teknik pengumpulan data yang dilakukan melalui suatu pengamatan, peneliti secara langsung turun ke lapangan untuk mengetahui keadaan objek yang sebenarnya.

3. Dokumentasi

Dokumentasi berasal dari kata dokumen yang disebutberupa barang-barang tertulis. Dalam melaksanakan metode dokumentasi ini, peneliti diharuskan mengamati benda-benda tertulis, misalnya buku- buku, majalah, dokumen, peraturan-peraturan, notulen rapat, dan sebagainya.

Analisis data adalah proses mencari dan menyusun secara sistematis data yang diperoleh dari hasil wawancara, catatan lapangan dan dokumentasi, Aktivitas dalam analisis data terdiri dari data reduction, data display, dan conclutions (Sugiyono, 2014 : 246).

1. Reduksi Data (Data Reduction) Reduksi data merupakan proses 
pemilihan, penyederhanaan, memfokuskan pada hal-hal penting dan transformasi data kasar yang muncul dari catatan-catatan tertulis di lapangan. Dalam hal ini maka setelah proses wawancara dan observasi dilakukan, peneliti mereduksi hasil temuan dan informasi terkait peran pemerintah dalam pembangunan ekonomi masyarakat.

Dengan demikian data yang telah direduksi akan memberikan gambaran yang lebih jelas, dan mempermudah peneliti untuk melakukan pengumpulan data selanjutnya, dan mencarinya bila diperlukan. Reduksi data dapat dibantu dengan peralatan elektronik seperti komputer mini, dengan memberikan kode pada aspek-aspek tertentu.

\section{Penyajian Data (Data Display)}

Penyajian data merujuk pada penyusunan sekumpulan informasi yang memberi kemungkinan adanya penarikan kesimpulan dan pengambilan tindakan.Beberapa data yang telah diperoleh dan disederhanakan, pada tahapan ini dilakukan penyajian data atau interpretasi data dalam sebuah naratif maupun grafik dan tabel. Pada penyajian data tersebut kemudian diikuti dengan adanya pengolahan data dari berbagai temuan yang diperoleh dilapangan dan menyandingkannya dengan berbagai teori terkait pembangunan ekonomi,.

\section{Kesimpulan (Conclutions)}

Pada tahapan ini dilakukan penarikan kesimpulan sebagai hasil dari proses analisa data. Kesimpulan yang diperoleh pada akhirnya akan menjawab sejumlah permasalahan yang terjadi ataupun jawaban dari rumusan masalah sehingga dapat memberikan gambaran tentang sesuatu yang dicari yakni terkait peran pemerintah dalam pembangunan ekonomi masyarakat, bahkan untuk dapat dijadikan sebagai temuan baru terhadap sebuah kajian bidang pengetahuan dan keilmuan.

Dalam penelitian ini menggunakan penelitian pendekatan kualitatif. (Sugiyono, 2014 : 125) mengajukan empat kriteria keabsahan dan keajegan yang diperlukan dalam suatu penelitian pendekatan kualitatif. Empat hal tersebut adalah Sebagai berikut :

1. Uji Credibility (validitas internal), untuk penelitian kualitatif pada tahapan ini menggunakan teknik triangulasi. Teknik triangulasi fungsinya sebagai alat untuk 
menguji kredibilitas data, yakni melalui penegcekan data dari berbagai sumber cara dan berbagi waktu. Berikut jenis triangulasi yang peneliti gunakan :

a. Triangulasi sumber, yakni teknik triangulasi yang dilakukan dengan cara mengecek data yang telah diperoleh melalui beberapa sumber yang berbeda untuk dianalisa, yang selanjutnya akan ditarik sebuah kesimpulan.

b. Triangulasi Teknik

Triangulasi Teknik, yaitu uji kredibilitas yang dilakukan dengan cara mengecek data kepada sumber yang sama, namun dengan teknik yang berbeda untuk menghasilkan sebuah kebenaran data.

c. Triangulasi Waktu

Triangulasi waktu merupakan teknik yang dilakukan dalam rangka pengujian kredibilitas data akibat adanya perbedaan waktu yang digunakan selama kegiatan observasi berlangsung, sehingga kepastian data dapat ditemukan.

2. Pengujian Transferability (validasi Eksternal),

hal ini berkenaan dengan pertanyaan hingga hasil penelitian dapat diterapkan dalam situasi lain. Dengan demikian hasil penelitian diharapkan dapat dijadikan sebagai referensi untuk di uji pada situasi yang bebeda.

3. Pengujian Depenability (reabilitas), pengujian ini dilakukan dengan melakukan audit terhadap keseluruhan proses penelitian.

\section{HASIL DAN PEMBAHASAN}

Berdasarkan hasil penelitian yang dilakukan dengan pendekatan interview dan observasi menunjukkan pramuwisata dibawah asuhan Dinas Pariwisata, Kebudayaan, Pemuda dan Olah Raga Kabupaten Sumenep sangat optimal terutama dalam memberikan pelayanan kepariwisataan di Kabupaten Sumenep, terlihat banyaknya wisatawan yang menggunakan jasa pramuwisata jika berkunjung ke tempat wisata, serta pramuwisata mampu memberikan informasi keadaan tempat wisata maupun menunjukkan berbagai budaya daerah wisata.

Optimalisasi pramuwisata dalam memandu wisatawan terlihat adanya pemenuhan kunjungan wisata ke Kabupaten Sumenep. Optimalisasi ini dilihat dari To Conduct To Direct yang mengatur dan melaksanakan kegiatan perjalanan wisata, dan To Point Out mengantarkan perjalanan wisatawan ke objek-objek dan daya tarik wisata yang dikehendaki, agar wisatawan merasakan kenyamanan serta To Inform, pramuwisata memberikan informasi dan 
penjelasan mengenai objek dan daya tarik wisata yang dikunjungi.

\section{To Conduct To Direct}

Pramuwisata telah mampu mengoptimalkan tugasnya dalam mengatur dan melaksanakan kegiatan perjalanan wisata bagi wisatawan dalam perjalanan wisata dengan memberikan pelayanan yang prima kepada wisatawan agar wisatawan saat bersama pramuwisata merasa nyaman dan memuaskan selama berwisata di Kabupaten Sumenep.

Wisatawan yang datang ke Kabupaten Sumenep dengan panduan pramuwiasata dengan berbagai religi sejarah serta pariwisata pantai yang memukau dan menawan, dlam pejalannya dengan bekerja sama dengan pramuwisata, dimana pramuwisata ini yang mengatur semua perjalanan wisata yang ingin dikunjungan tentunya ada perjanjian terlebih dahulu dengan agent wisata perjalanan di Sumenep.

Keadaan demikian menunjukkan adanya optimalisasi kerja pramuwisata yang baik dalam melakukan pendampingan maupun mengantarkan wisatawan ketempat wisata dengan pelayanan yang baik dan menyenangkan, sehingga dengan adanya pramuwisata menambah ketertarikan wisatawan untuk berkunjung kembali.

Keadaan yang demikian sesuai dengan penelitian Sang Nyoman Bagus
Satya Wira (2019), Peran Pramuwisata Dalam Promosi Kepariwisataan Di Bali. Hasil penelitian menunjukkan Sistem promosi pariwisata Bali adalah suatu sistem yang regulasinya ditetapkan berdasarkan peraturan perundang- undangan, yakni UU Nomor 10 Tahun 2009 tentang Kepariwisataan dan Perda Provinsi Bali Nomor 2 Tahun 2012 tentang Kepariwisataan Budaya Bali. Komponen dari sistem tersebut terdiri dari pemerintah (Disparda Provinsi Bali dan BPPD Provinsi Bali), asosiasi anggota dari GIPI Provinsi Bali (utamanya ASITA), usaha biro perjalanan wisata dan pramuwisata, usaha lainnya yang bergerak di bidang pariwisata, dan masyarakat.Mekanisme kerja sistem terdiri dari promosi destinasi dan produk; promosi langsung dan tidak langsung; promosi online dan offline; serta promosi formal dan informal.

Optimalisasi atau taktik sebagai pramuwisata dalam pendekatan secara keseluruhan yang berkaitan dengan pelaksanaan gagasan, perencanaan, dan eksekusi sebuah aktivitas dalam kurun waktu tertentu dalam meningkatkan dan mengembangkan wisata yang ada.

\section{To Point Out}

Pramuwisata secara optimal telah menunjukkan adanya pelayanan kepariwisataan yang baik dalam mengantarkan perjalanan wisatawan ke objek-objek wisata yang dikehendaki 
wisatawan, agar daya tarik wisata selama bersama pramuwisata merasakan kenyamanan dalam berwisata serta secara optimal pramuwisata telah memberikan rasa keamanan selama melakukan kunjungan wisata ke Kabupaten Sumenep.

Pramuwisata ini sebagai oragnisasi yang merupakan binaan dari Dinas Pariwisata, Kebudayaan, Pemuda dan Olah Raga Kabupaten Sumenep senantiasa dengan perilaku dan etika pariwisata yang sangat menyenangkan, karena Pramuwisata yang ditunjuk dalam mengantarkan wisatawan telah diberi bekal pengetahuan wisata maupun etika dengan wisatawan, yang kesemua ini untuk memberikan rasa kenyamanan dan memuaskan bagi wisatawan bila diantarkan pramuwisata.

Keadaan demikian sesuai dengan penelitian Wijaya (2019), Peran Pramuwisata Di Kawasan Konservasi Geopark, Batur Kintamani. Hasil penelitian menunjukkan Keberadaan pramuwisata lokal sebagai pemandu wisatawan dalam aktivitas pendakian di gunung Batur menentukan keberlanjutan suatu kawasan konservasi.Dari variable yang telah ditentukan, ditemukan bahwa variable utama dari peran pramuwisata yaitu tiga sub indikator berada pada kategori cukup setuju dengan skor 52,8 persen, 59,4 persen dan 50 persen. Sub indicator dengan kategori tersebut merupakan sub indicator penting yang menjelaskan idealnya peran utama pramuwisata di wilayah konservasi. Namun sub indikator tersebut ternyata memperoleh hasil yang rendah.

Pengembangan kawasan wisata merupakan alternatif yang diharapkan mampu mendorong baik potensi ekonomi maupun upaya pelestarian. Pengembangan kawasan wisata dilakukan dengan menata kembali berbagai potensi dan kekayaan alam dan hayati secara terpadu. Pada tahap berikutnya dikembangkan model pengelolaan kawasan wisata yang berorientasi pelestarian lingkungan.

\section{To Inform}

Pramuwisata telah optimal dalam memberikan informasi wisata dan penjelasan mengenai objek maupun daya tarik wisata yang dikunjungi, informasi sejarah dan budaya, dan berbagai informasi lainnya kepada wisata dengan senang hati dan perasaan yang menyenangkan, sehingga wisatawan merasa nyaman dan aman bila berwisata ke Sumenep.

Pengembangan wisata di Kabupaten Sumenep itu tentunya tidak terlepas dari faktor-faktor pendukung untuk dapat memberikan kemudahan bagi wisatawan di tempat wisata termasuk juga pemandu wisata, sehingga wisatawan merasakan adanya kenyamanan dan ketenagan saat berwisata.

Pramuwisata yang merupakan binaan dari Dinas Pariwisata, Kebudayaan, 
Pemuda dan Olah Raga Kabupaten Sumenep senantiasa dapat memberikan informasi yang menarik perhatian wisatawan, karena ini sebagai promosi dalam memperkenalkan wisata, sehingga wisatawan merasa senang atas pemberian informasi yang dilakukan. Keadaan demikian menunjukkan adanya pengetahuan pramuwisata dalam kepariwisatawan maupun tata kelola wisata yang sangat tepat, sehingga penjelasan yang diberikan dapat memberikan rasa kepercayaan yang mendalam bagi wisatawan.

Keadaan yang demikian sesuai dengan penelitian Made Artajaya (2016), Tuntutan Kerja Pramuwisata Berbahasa Jerman Dalam Era Globalisasi Pada Biro Perjalanan Wisata Di Kabupaten Badung. Hasil penelitian menunjukkan meningkatnya jumlah kunjungan wisatawan berbahasa Jerman ke Bali, diikuti juga dengan tumbuhnya biro-biro perjalanan wisata baru yang juga menyasar pangsa pasar wisatawan berbahasa Jerman. maka dapat ditarik simpulan bahwa penurunan jumlah kunjungan wisatawan Jerman yang menggunakan jasa biro perjalanan wisata secara otomatis berpengaruh terhadap turunnya intensitas pemanduan wisata yang diberikan perusahaan kepada pramuwisata berbahasa Jerman. Sehingga para pramuwisata berbahasa Jerman harus mampu bersaing untuk mendapatkan pekerjaan secara profesional, melakukan promosi baik atas nama perusahaan maupun pramuwisata melakukan pekerjaan kepemanduan.

Strategi promosi pada dasarnya dapat diintegrasikan untuk mempromosikan barang atau jasa. Namun dalam pengintegrasian tersebut perlu diperhatikan jenis barang atau jasa yang ada serta besarnya bagian dari bauran promosi yang akan digunakan. Orang orang melakukan komunikasi mempunyai beberapa alasan antara lain: mencari kesenangan, mencari bantuan, instruksi, memberikan informasi, mengemukakan ide atau pendapat yang bersifat informasi dianggap lebih sesuai.

\section{PENUTUP}

Berdasarkan hasil penelitian menunjukkan pramuwisata dibawah bimbingan Dinas Pariwisata, Kebudayaan, Pemuda dan Olah Raga Kabupaten Sumenep dapat memberikan pelayanan kepariwisataan yang sangat optimal kepada wisatawan yang berkunjung objek wisata di Kabupaten Sumenep. Optimalisasi tersebut ditunjukkan dengan To Conduct To Direct yang mengatur dan melaksanakan kegiatan perjalanan wisata, dan To Point Out mengantarkan perjalanan wisatawan ke objek-objek dan daya tarik wisata yang dikehendaki, agar wisatawan merasakan kenyamanan serta To Inform, pramuwisata 
memberikan informasi dan penjelasan mengenai objek dan daya tarik wisata yang dikunjungi. Berdasarkan fokus yang diteliti, maka didapat hasil penelitian, sebagai berikut :

1. To conduct to direct yang dilakukan Pramuwisata telah mampu mengoptimalkan kerjanya dalam mengatur dan melaksanakan kegiatan perjalanan wisata bagi wisatawan dengan memberikan pelayanan yang prima kepada wisatawan agar wisatawan saat bersama pramuwisata.

2. To Point Out yang dilakukan oleh Pramuwisata telah optimal dalam pelayanan kepariwisataan yang baik mengantarkan perjalanan wisatawan ke objek-objek wisata yang dikehendaki wisatawan, agar daya tarik wisata selama bersama pramuwisata merasakan kenyamanan.

3. To Inform yang dilakukan Pramuwisata telah optimal memberikan informasi wisata dan penjelasan mengenai asal usul objek wisata maupun daya tarik wisata yang dikunjungi, informasi sejarah dan budaya.

Beberapa saran yang dapat diberikan dalam penelitian ini sebagai penyempurnaan selanjutnya, adalah :

1. Diharapkan to conduct to direct yang dilakukan Pramuwisata untuk lebih dioptimalkan dan ditingkatkan, terutama dalam mengatur dan melaksanakan kegiatan perjalanan wisata dengan mengajak wisatawan berkunjung ke Sumenep.

2. Diharapkan to point out yang diberikan Pramuwisata untuk lebih ditingkatkan dalam menunjukkan adanya pelayanan kepariwisataan yang baik ke objek-objek wisata agar kepuasan wisatawan lebih meningkatkan, dalam melakukan perjalanan wisata,

3. Diharapkan To Inform yang dilakukan Pramuwisata dapat lebih efektif dalam memberikan informasi wisata dalam mengenal tempat dan budaya wisata agar informasi yang diberikan kepada wisatawan tidak bertentangan dengan objek yang sebenarnya.

\section{DAFTAR PUSTAKA}

Ahdinoto, Tomy, 2014, Interpretasi Dan Teknik Pemandu Wisata. Bandung. Asita.

Andriyani Yesy. 2015. Profesionalisme Kerja Pegawai Dalam Penyelenggaraan Administrasi Pelayanan Publik Di Kecamatan Samarinda Utara Kota Samarinda. eJournal Administrasi Negara, Vol 4, Nomor 1, $2016: 2320-2333$

61 | Jurnal Public Corner Fisip Universitas Wiraraja 
Amrullah, Zaenudin, 2010, Pemberdayaan Masyarakat Berbasis Pariwisata, Jakarta : PT. Raja Grafindo Persada Anoraga, Pandji, 2016, Manajemen Bisnis.

Jakarta: PT. Rineka Cipta.

Badrudin, Rudy, 2011, Menggali Sumber Pendapatan Asli Daerah (PAD) Daerah Istimewa Yogyakarta Melalui Pembangunan Industri Pariwisata, Jurnal Kompak, 1-13, 2001.

Freddy, Rangkuty, 2011, SWOT Balanced Scorecard. Jakarta: PT Gramedia,

Hamalik, Oemar, 2010, Proses Belajar Mengajar. Jakarta: Salemba Empat

Irawati L, 2013, Pelaksanaan Pendidikan dan Pelatihan (DIKLAT) Pemandu Wisata untuk Meningkatkan Kompetensi Pemandu Wisata.

Jatman, 2002, Mengembangkan Budaya Kerja, Semarang: Jayakarta,

Keraf, A.Sonny Robert Haryono Imam 2008, Keraf, Manajemen, Jakarta: Gramedia.

Kurniawan, Agung. 2005. Transformasi Pelayanan Publik. Yogyakarta: Pembaharuan.

Moleong, L. 2014. Metodologi Penelitian Kualitatif. Edisi Revisi. Bandung: PT Remaja Rosdakarya.

Muljadi A.J, 2014, Kepariwisataan dan Perjalanan, Jakarta : PT. Raja Grafindo Persada,
Poerdwadarminta, 2012, Kamus Besar

Bahasa Indonesia, Jakarta:

Balai Pustaka,.

Muhajir, 2015, Menjadi Pemandu Wisata Pemula. Jakarta: Grasindo.

Nuriata, 2015, Teknik PemanduanInterpretasi dan Pengaturan Perjalanan Wisata. Bandung: Alfabeta.

Ramly, Abdullah,2011, Pembelajaran Berbasis Pemanfaatan Sumber Belajar. Jurnal Ilmiah DIDAKTIKA Vol. XII No. 2, 216-231. Tersedia Online.

Siagian P, Sondang, 2015, Manajemen Sumber Daya Manusia. Jakarta: PT. Bumi Aksara.

Silalahi, Ulber. 2010. Metode Penelitian Sosial. Bandung: PT. Refika Aditama.

Sugiyono. 2011. Metodologi Penelitian Kualitatif $R \& D . \quad$ Bandung : Alfabeta.

Sumarsono, Sonny. 2009. Ekonomi Sumber Daya Manusia Teori dan Kebijakan Publik. Yogyakarta: Graha Ilmu.

Sumitro Maskun, 2017, Profesi Aparatur Negara dalam Birokrasi Indonesia, Makalah disajikan pada seminar Nasional Ilmu-ilmu social 1997 Medan , 19 Maret 1991.

Surjanto Dalam A. Hari Karyono. 1997. 
Kepariwisataan. Jakarta: Grasindo.

Sutejo, 2014, Pemberdayaan dan Kesejahteraan Keluarga, Jakarta: Azka Press.

Suwantoro, Gamal, 2011, DasarDasar Pariwisata. Jakarta, Salemba Empat.

Udoyono, Bambang, 2008, Sukses Menjadi. Pramuwisata Profesional. Jakarta : Kesaint.

Umar, Husein. 2014. Metode Penelitian untuk Skripsi dan Tesis Bisnis edisi kedua. Jakarta : PT Raja Grafindo.

Yoeti Oeka, 2013, Perencanaaan dan Pengembangan Pariwisata. Jakarta. Pradaya. Pratama,

Winardi, J, 2014, Motivasi \& Pemotivasian Dalam Manajemen, Jakarta: PT Raja. Grafindo,

\section{Perundang- Undangan}

Undang-Undang Republik Indonesia Nomor 10 Tahun 2009 Tentang Kepariwisatawan

\section{Jurnal}

Fransiska Fila Hidayana (2020),

Keberadaan Pramuwisata Ilegal Di

Bali. Jurnal Mallinosata Volume 5 No.1, Juli 2020,

I Dewa Ayu Hendrawathy Putri (2018),

Strategi Komunikasi Pramuwisata 63 Jurnal Public Corner Fisip Universitas Wiraraja dalam Menjaga Eksistensi Pariwisata Bali. Pariwisata Budaya, Vol.3 Nomer 1,Tahun 2018

Made Artajaya (2016), Tuntutan Kerja Pramuwisata Berbahasa Jerman Dalam Era Globalisasi Pada Biro Perjalanan Wisata Di Kabupaten Badung. Vol. 7 No. 1, Desember 2016 ISSN 2087 5576

Sang Nyoman Bagus Satya Wira (2019), Peran Pramuwisata Dalam Promosi Kepariwisataan Di Bali. JUMPA, Volume 05, Nomor 02, Januari 2019,

Wijaya (2019), Peran Pramuwisata Di Kawasan Konservasi Geopark, Batur Kintamani. Jurnal IPTAP Vol. 7 No. 1, Juli 2019 -ISSN :

2338-8633 e-ISSN : 2548-7930 